2. Arthur M. McAnally and Robert B. Downs, "The Changing Role of Directors of University Libraries," College and Research Libraries 34:103 (Mar. 1973).

3. Louis Kaplan, "Letter to the Editor: Directors of University Libraries," College and Research Libraries 38:521 (Nov. 1977).

4. Jerry L. Parsons, "How Have They Changed? Characteristics of Research Library Directors, 1958 and 1973," Wilson Library Bulletin 50:613;617 (Apr. 1976).

5. William L. Cohn, "An Overview of ARL Directors, 1933-1973," College and Research Libraries 37:137; 143-44 (Nov. 1976).

6. Julie A. C. Virgo, Sarah How, and Annette Fern, comps., ACRL University Library Statistics, 1978-1979: A Compilation of Statistics From Ninety-Eight Non-ARL University Libraries (Chicago: American Library Association, 1980), p.1b. Six libraries with vacant or acting director positions were not included in the survey.

7. Parsons, p.613.

8. Parsons, p.614.

9. Organization and Staffing of the Libraries of Columbia University, a Case Study, prepared by Booz, Allen, and Hamilton, Inc., sponsored by the Association of Research Libraries and others (Westport, Conn.: Redgrave Information, 1973), p.45.

10. Parsons, p.616.

11. Parsons, p.614.

12. Cohn, p.141.

13. Parsons, p.617.

14. For a brief discussion on the mobility of women directors, see William S. Wong and David S. Zubatsky, "The First-Time Appointed Academic Library Directors, 1970-1980, A Profile," Journal of Library Administration 4:43-44 (Spring 1983).

\title{
Changes in Rank Lists of Serials Over Time: Interlending versus Citation Data
}

\section{Maurice B. Line}

The British Library Lending Division carried out three major surveys of its lending patterns in 1975,1980 , and 1983. The rank list of serials requested for loan showed considerable variation over time. There was also low overlap in the top titles requested. A comparison was made of these rankings with the rankings from Journal Citation Reports (JCR) produced by the Institute for Scientific Information. The JCR rankings had a high degree of overlap, 95 percent for the top 100 in Science Citation Index, while the Lending Division had only a 57 percent overlap. The reasons for this variation are discussed.
Three major surveys carried out by the British Library Lending Division in 1975, 1980 , and $1983^{1,2,3}$ produced rank lists of serials in order of demand. Comparisons of these rank lists showed very considerable changes over time, suggesting that it might be dangerous to rely unduly on a rank list relating to one year. Changes in the precise rank order would be expected; what was unexpected was the low overlap in the top titles requested.

For interest, a similar comparison was made between the rank lists produced by the Institute for Scientific Information and

Maurice B. Line is director general of the British Library Lending Division, Boston Spa, Wetherby, West Yorkshire LS23 7BQ, United Kingdom. This note also appeared in Interlending and Document Supply 12 (Oct. 1984).

I am grateful to Betty Smith, bibliographic research officer at the British Library Lending Division, for doing the comparisons between the ISI rank lists; and to Trevor Palmer, of the Lending Division's Research Section, for making comments and suggestions on a draft of this note. 
published annually as Journal Citation Reports (JCR) - a volume of the annual Science Citation Index $(S C I)$ and Social Science Citation Index (SSCI). The results are given in table 1 . Nineteen eighty-three data were not available for either $S C I$ or $S S C I$, and SSCI data were not available for years earlier than 1977; the nearest approximations were therefore used for comparison.

The differences are striking. At the most extreme, there was 95 percent overlap in SCI's top one hundred in 1979 and in 1982, compared with only 57 percent in the Lending Division's top one hundred in 1980 and 1983. At the least extreme, there was a 78 percent overlap in $S S C I$ 's top two hundred in 1977 and in 1982, compared with 56 percent in the Lending Division's top two hundred in 1975 and in 1980 . The high overlap in the ISI lists is remarkable, since, as Urquhart pointed out, there are good statistical reasons for expecting substantial change. ${ }^{4}$

What are the reasons for these large differences between Lending Division and ISI data? The absence of humanities titles from $J C R$ will not have had any effect, because there are very few humanities serials among the titles most requested from the Lending Division. One obvious explanation is sampling error, which would apply to the Lending Division data but not to ISI's, which are compiled from a whole population of citations. A considerable difference in the precise rank order in the Lending Division lists would be expected. However, the actual numbers of requests for the most used serials in the Lending Division samples are large, and sampling error alone is very unlikely to account for the much smaller overlap, especially as both comparisons (1975-80 and 1980-83) yield similar results.

Another explanation, which is likely to be nearer the truth, is that interlibrary loan (ILL) demand is subject to much more fluctuation than citations in journals; it is affected by local finances-for example, budgetary restrictions may favour more ILL demand because acquisitions are reduced, or less because economies may be sought in interlibrary borrowing. The relative volume of demand made by academic and industrial libraries may change substantially (there was in fact a shift towards industrial library use between 1980 and 1983 , though it was not very large and is unlikely to have had more than a small effect on the rank order). Interests change: journals in the life sciences and related subjects and in electronic technology rose up the lists between 1975 and 1983 at the expense of such subjects as pure chemistry and physics. This is a known element in the differences between Lending Division lists, but one might expect it also to apply to the ISI lists, if one dismisses the possibility that interests in the U.K. (from which about three-quarters of serial demand on the Lending Division comes) change more quickly than interests in the world at large, the U.S. in particular.

However, one major difference between citations and ILL demands is that citations

TABLE 1

SIMILARITY OF RANK LISTS OF SERIALS AT THREE-YEAR AND FIVE-YEAR INTERVALS: ILL DATA VERSUS CITATION DATA

\begin{tabular}{|c|c|c|c|c|c|c|}
\hline \multirow[b]{2}{*}{$\begin{array}{c}\text { Top } \times \text { titles } \\
\text { on lists }\end{array}$} & $\begin{array}{c}\text { Req } \\
\text { Lenc }\end{array}$ & $\begin{array}{l}\text { rom } \\
\text { ision }\end{array}$ & $\%$ of Titles C & to Both List & & $\begin{array}{l}\text { nce } \\
\text { dex }\end{array}$ \\
\hline & $\begin{array}{c}1975 / 1980 \\
(5 \text { years) }\end{array}$ & $\begin{array}{c}1980 / 1983 \\
\text { (3 years) }\end{array}$ & $\begin{array}{c}1975 / 1980 \\
\text { (5 years) }\end{array}$ & $\begin{array}{c}1979 / 1982 \\
\text { (3 years) }\end{array}$ & $\begin{array}{c}1977 / 1982 \\
(5 \text { years) }\end{array}$ & $\begin{array}{c}1979 / 1982 \\
\text { (3 years) }\end{array}$ \\
\hline $\begin{array}{r}100 \\
200 \\
300 \\
400 \\
500 \\
1,000\end{array}$ & $\begin{array}{l}60 \\
56 \\
54 \\
56 \\
56 \\
56\end{array}$ & $\begin{array}{l}57 \\
62 \\
61 \\
62 \\
61 \\
60\end{array}$ & $\begin{array}{l}88 \\
83 \\
86 \\
88 \\
87 \\
83\end{array}$ & $\begin{array}{l}95 \\
93 \\
93 \\
91 \\
92\end{array}$ & $\begin{array}{l}83 \\
78 \\
81 \\
79 \\
80\end{array}$ & $\begin{array}{l}88 \\
84 \\
87 \\
88 \\
87\end{array}$ \\
\hline
\end{tabular}

To be read as follows: Of the top 100 titles in the 1975 and $1980 \mathrm{ILL}$ rank lists, 60 percent were common to both; of the top 300 titles in the 1979 and 1982 SCI rank lists, 93 percent were common to both. 
are made mainly by authors in academic institutions, whereas ILL demands for serials come about equally from academic institutions and from industrial and commercial organizations (in fact, both categories accounted for 35 percent of demand for serials in another survey carried out in 1983 at the Lending Division). Possibly academic requests show more stability than other ILL requests: the data collected by the Lending Division did not include information on requesting organizations, so it is not possible to test this hypothesis. The upsurge of interest in biotechnology, bioengineering, other life science-related subjects, and electronic technology would be reflected more rapidly in industry than in academic institutions, where relatively little staff movement would have occurred over a short period and where the existing staff would presumably have continued to write and cite as before, whether they are physicists or biochemists. There are other reasons why citation rank lists might show more stability. Serials cited most are likely to be more "academic" in nature, and these may constitute a more stable population than serials aimed at the industrial market. Self-citation (by serials and authors) would favour stability, as would the fact that some works are cited repeatedly, not necessarily because they are used very heavily but because they are standard papers that must be cited or because they are 'lifted' from bibliographies in other articles. These factors would not only help to explain the differences between the ISI rank list comparisons and the Lending $\mathrm{Di}$ vision comparisons, but they would mean that citations, while they might reflect tolerably well the use being made of academic libraries as a whole (not in individual libraries, where local factors are likely to be influential), are a poor indicator of total serial uses.

It may well be that the instability of the Lending Division rank lists is a little 'unreal,' in the sense that a longer survey period or a much larger sample would reduce the differences. The stability of the ISI rank lists is likely to bear much less relation to reality, in that citations are much more stable than actual uses. Whatever the reasons for the differences described, they are a matter of some practical interest. A national core collection of serials designed to serve academic institutions might be identified, with more confidence that it would be reasonably stable over a period of time than a collection aiming to serve all types of organizations, let alone one designed to serve mainly industry. More research into this matter is desirable.

\section{REFERENCES}

1. C. A. Bower, "Patterns of Use of the Serial Literature at the BLLD," BLL Review 4:31-36 (1976).

2. Ann Clarke, "The Use of Serials at the British Library Lending Division," Interlending Review 9:111-17 (Oct. 1981).

3. Karen Merry and Trevor Palmer, "Use of Serials at the British Library Lending Division in 1983," Interlending and Document Supply 12:53-56 (Apr. 1984).

4. J. A. Urquhart, "Has Poisson Been Kicked to Death? A Rebuttal of the British Library Lending Division's Views on the Inconsistency of Rank Lists of Serials," Interlending Review 10:97-99 (Nov. 1982). 


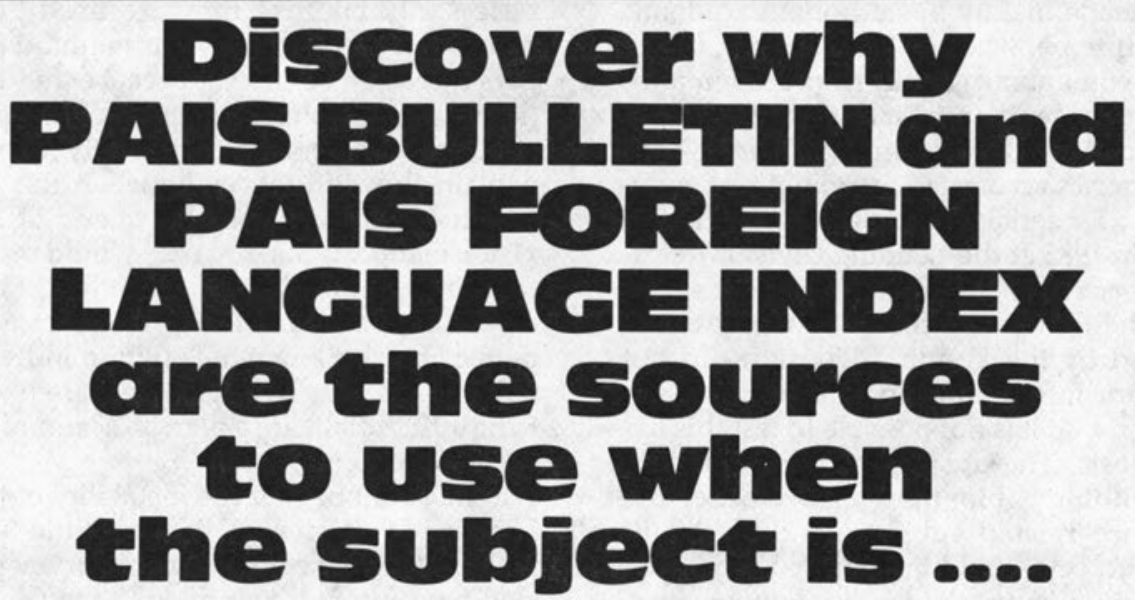

- Economics - Business - Finance

- Public Policy Issues - Statistics

- International Relations

- Trade and Commerce

- Political Science

- Government

It's no mystery why thousands of people use PAIS. They know that when it comes to coverage of the social sciences, PAIS is unmatched in its breadth of coverage and in the quality of the information it contains.

PAIS' coverage is more than just political science and government. Fields such as business, economics, statistics, and international trade are also covered in depth. And the PAIS source list includes more than just journals. Books, government documents, conference proceedings, statistical reports, hearings, and many other sources are carefully examined for vital new information.

All the evidence points towards the use of PAIS. Examine the PAIS BULLETIN and the PAIS FOREIGN LANGUAGE INDEX closely next time you are searching for information on any important public issue.

\section{Public Affairs Information Service}

11 W. 40th Street $\bullet$ New York, NY $10018 \bullet(212) 736-6629$

Serving information seekers since 1914.

PAIS is also available online through DIALOG, BRS, and Data-Star. 